\title{
Pengembangan Perangkat Pembelajaran Matematika Berbasis Model Problem Based Learning untuk Memfasilitasi Kemampuan Pemecahan Masalah Matematis Peserta Didik Kelas VIII SMP
}

\author{
Frengki Candra Gunawan Silalahi ${ }^{1}$, Kartini ${ }^{2}$, Nahor Murani Hutapea ${ }^{3}$ \\ 1, 2, 3 Program Pascasarjana Pendidikan Matematika, Universitas Riau, \\ Jl. H.R Soebrantas, Riau, Indonesia \\ Frengki_silalahi@yahoo.com
}

\begin{abstract}
The background of this study is the lack of problem-solving ability of students learning mathematics due to the tool can not encourage this ability. This study aims to develop mathematics learning tool with a problem based learning (PBL) model that meets valid and practical requirements to facilitate the students' mathematical problem-solving abilities in relation and function material. The development model used is the 4D model (define, design, develop, desseminate) by Thiagarajan, Semmel, and Semmel. The instrument used for validation was the validation sheet of learning tools (syllabus, lesson plan, and student worksheet) and the practical instrument was the student' questionnaire. The techniques in this study were data collection techniques and data analysis. The study subjects were students of class VIII at SMP Darma Yudha in the academic year 2020/2021. Based on the results of data analysis, it is concluded that the mathematics learning tool is valid. The results of the validation of the syllabus is $84 \%$ in the valid category, the lesson plan is $87 \%$ with the very valid category, student worksheet is $85 \%$ with the very valid category. Therefore, the learning tools developed can be applied for students. Based on the results of small group trials, the mathematics learning tools met the practical requirements with average questionnaire result of students' responses up to $81 \%$ with the practical category. Therefore, these tools can be used by students well.
\end{abstract}

Keywords: Learning Tools, PBL, Mathematical Problem Solving Ability

\begin{abstract}
Abstrak
Penelitian ini dilatarbelakangi oleh kurangnya kemampuan pemecahan masalah peserta didik dikarenakan perangkat pembelajaran matematika yang belum bisa membuat tercapainya salah satu tujuan tersebut. Tujuan penelitian ini untuk mengembangkan perangkat pembelajaran matematika dengan model problem based learning (PBL) yang memenuhi syarat valid dan praktis dalam memfasilitasi kemampuan pemecahan masalah matematis peserta didik pada materi relasi dan fungsi. Model pengembangan yang digunakan adalah model 4D (define, design, develop, desseminate) yang dirancang oleh Thiagarajan, Semmel, dan Semmel. Instrumen yang digunakan untuk validasi adalah lembar validasi perangkat pembelajaran (silabus, RPP, dan LKPD) serta instrumen kepraktisan adalah angket respon peserta didik. Teknik yang digunakan adalah teknik pengumpulan data dan analisis data. Subjek penelitian yaitu peserta didik kelas VIII SMP Darma Yudha tahun ajaran 2020/2021. Berdasarkan hasil analisis data disimpulkan bahwa perangkat pembelajaran matematika sudah valid. Hasil validasi silabus mencapai $84 \%$ dengan kategori valid, RPP mencapai $87 \%$ dengan kategori sangat valid, LKPD mencapai $85 \%$ dengan kategori sangat valid. Artinya perangkat pembelajaran yang dikembangkan dapat diujicobakan. Hasil uji coba kelompok kecil disimpulkan bahwa perangkat pembelajaran matematika memenuhi syarat praktis dengan rata-rata hasil angket respon peserta didik mencapai $81 \%$ dengan kategori praktis. Artinya perangkat yang telah diujicobakan dapat digunakan dengan baik oleh peserta didik.
\end{abstract}

Kata Kunci: Perangkat Pembelajaran, PBL, Kemampuan Pemecahan Masalah Matematis.

Copyright (c) 2021 Frengki Candra Gunawan Silalahi, Kartini, Nahor Murani Hutapea $\triangle$ Corresponding author: Frengki Candra Gunawan Silalahi

Email Address: frengki_silalahi (Jl. H.R Soebrantas, Riau)

Received 04 November 2020, Accepted 29 Desember 2020, Published 13 Februari 2021

\section{PENDAHULUAN}

Pemecahan masalah merupakan salah satu tujuan pembelajaran matematika dalam kurikulum 2013, meliputi kemampuan memahami masalah, merancang model matematika, 
menyelesaikan model, dan menafsirkan solusi yang diperoleh. Rezi Ariawan (2016) menyatakan bahwa kemampuan pemecahan masalah matematis merupakan kemampuan yang sangat penting dan menjadi fokus utama untuk dikembangkan dan dimiliki oleh peserta didik melalui pembelajaran matematika di sekolah. Hal ini sejalan dengan Branca (dalam Sovia Ulva dan Ekasatya, 2016) menyatakan bahwa pemecahan masalah matematis merupakan salah satu tujuan penting dalam pembelajaran matematika bahkan proses pemecahan masalah matematis merupakan jantungnya matematika.

Pentingnya kemampuan pemecahan masalah matematis tidak sejalan dengan hasil yang diperoleh dilapangan. Siti Mawaddah dan Hana Anisah (2015) dalam penelitiannya menunjukkan bahwa beberapa peserta didik kesulitan dalam memecahkan masalah matematika yang tidak rutin. Hasil TIMSS (Trend in International Mathematics and Science Study) tahun 2015 menunjukkan siswa Indonesia berada di peringkat 44 dari 49 negara. Hasil Program for International Student Assesment (PISA) tahun 2018 menunjukkan bahwa peserta didik Indonesia mendapat peringkat 72 dari 77 negara di dunia. Berdasarkan masih rendanya kemampuan pemecahan masalah matematis peserta didik, perlu dikembangkan suatu perangkat pembelajaran yang dapat membantu peserta didik dalam meningkatkan kemampuan pemecahan masalahnya.

Siti Mawadah dan Hana Anisah (2015) juga menyatakan bahwa guru harus membantu peserta didik memberikan kebermaknaan dalam belajar matematika serta membangun kemampuan pemecahan masalah matematis peserta didik untuk memperdalam pemahaman siswa terhadap matematika. Sagala (2011) menyatakan bahwa guru harus memiliki metode dalam pembelajaran sebagai strategi yang dapat memudahkan peserta didik untuk menguasai ilmu pengetahuan yang diberikan. Dalam upaya meningkatkan kemampuan pemecahan masalah matematis peserta didik, diperlukan proses pembelajaran yang sesuai dan sejalan dengan kurikulum. Kurikulum yang berlaku saat ini adalah kurikulum 2013 yang dalam pelaksanaannya menggunakan pendekatan saintifik (ilmiah).

Salah satu model pembelajaran yang direkomendasikan dalam kurikulum 2013 yang dapat digunakan untuk meningkatkan kemampuan peserta didik yaitu Problem Based Learning (PBL) (Arends, 2012). Arends (2008) menyatakan bahwa problem based learning dirancang untuk membantu peserta didik mengembangkan keterampilan berpikir, keterampilan menyelesaikan masalah, dan keterampilan intelektualnya. Hasil penelitian yang dilakukan Sumartini (2016), dan Wahyu Hidayat, (2018), menunjukkan bahwa KPMM peserta didik meningkat dengan digunakannya model PBL. Jadi, model PBL cocok digunakan untuk memfasilitasi KPMM peserta didik sehingga perlu diupayakan pembelajaran dengan model PBL.

Titi (2017) mengatakan pelaksanaan kurikulum 2013 berjalan baik jika dilakukan dengan berbagai persiapan, termasuk persiapan guru terkait implementasi kurikulum 2013. Salah satu wujud persiapan yang dilakukan guru adalah mempersiapkan perangkat pembelajaran yang mendukung dalam menjalankan kurikulum 2013, termasuk pada mata pelajaran matematika. Perangkat 
Pengembangan Perangkat Pembelajaran Matematika dengan Penerapan Model Problem Based Learning (PBL) untuk Memfasilitasi Kemampuan Pemecahan Masalah Matematis Peserta Didik Kelas VIII SMP, Frengki Candra Gunawan Silalahi, Kartini, Nahor Murani Hutapea

115

pembelajaran sangat penting, karena merupakan acuan guru untuk melaksanakan kegiatan pembelajaran supaya lebih terarah dan sistematis. Trianto (2009) perangkat pembelajaran adalah perangkat yang digunakan dalam proses pembelajaran.

Pentingnya mempersiapkan perangkat pembelajaran yang dapat dijadikan acuan dalam proses pembelajaran, tidak sejalan dengan kenyataan yang ditemukan. Kenyataan menunjukkan bahwa hanya sebagian guru mempersiapkan perangkat pembelajaran dalam rangka melakukan perencanaan proses pembelajaran. Sebagaimana diperoleh dari hasil wawancara guru matematika di beberapa SMP di Pekanbaru guru belum membuat RPP yang sesuai dengan kurikulum 2013. Berdasarkan hasil observasi dan analisis yang peneliti lakukan terhadap perangkat pembelajaran yang digunakan guru di beberapa SMP Pekanbaru, diperoleh informasi bahwa perangkat pembelajaran yang dibuat guru masih terdapat kelemahan yang perlu diperbaiki. Salah satu kelemahan RPP yang disusun guru yaitu pengembangan indikator pencapaian kompetensi berdasarkan KD belum menggunakan kata kerja operasional (KKO) yang tepat. Contoh kelemahan RPP terlihat pada Gambar 1 berikut.

\begin{tabular}{|c|c|c|c|}
\hline \multicolumn{2}{|r|}{ KOMPETENSI DASAR } & \multicolumn{2}{|r|}{$\begin{array}{c}\text { INDIKATOR PENCAPAIAN } \\
\text { KOMPETENSI }\end{array}$} \\
\hline 3.3 & $\begin{array}{l}\text { Mendeskripsikan dan } \\
\text { menyatakan relasi dan } \\
\text { fungsi dengan } \\
\text { menggunakan berbagai } \\
\text { representasi (kata-kata, } \\
\text { tabel grafik, diagram, dan } \\
\text { persamaan). }\end{array}$ & $\begin{array}{l}3.3 .1 \\
3.3 .2 \\
3.3 .3\end{array}$ & $\begin{array}{l}\text { Mendefinisikan relasi } \\
\text { Memberikan contoh relasi dalam kehidupan } \\
\text { sehari-hari } \\
\text { Menunjukkan suatu relasi dengan diagram } \\
\text { panah, diagram kartesius, dan pasangan } \\
\text { berurutan. } \\
\text { Menunjukkan suatu fungsi dengan himpunan } \\
\text { pasangan berurutan dengan diagram panah, } \\
\text { rumus fungsi, tabel dan grafik. } \\
\text { Menunjukkan hasil produk kartesius dari dua } \\
\text { himpunan yang diketahui } \\
\text { Menjelaskan hubungan relasi dan fungsi } \\
\text { Membedakan antara fungsi dan bukan fungsi }\end{array}$ \\
\hline 4.3 & $\begin{array}{l}\text { Menyelesaikan masalah } \\
\text { yang berkaitan dengan } \\
\text { relasi dan fungsi dengan } \\
\text { menggunakan berbagai } \\
\text { representasi. }\end{array}$ & $\begin{array}{l}4.3 .1 \\
4.3 .2\end{array}$ & $\begin{array}{l}\text { Menyatakan suatu relasi yang terkait dengan } \\
\text { kejadian sehari-hari } \\
\text { Menyatakan suatu fungsi yang terkait } \\
\text { dengan kejadian sehari-hari }\end{array}$ \\
\hline
\end{tabular}

Gambar 1 Contoh KD \& Indikator Pencapaian Kompetensi pada RPP

Pada Gambar 1 terlihat bahwa kata kerja yang digunakan belum operasional sehingga belum menggambarkan ketercapaian KD. Hal ini sejalan dengan pendapat Trianto (2015) tentang salah satu prinsip mengembangkan RPP yaitu kompetensi yang direncanakan dalam RPP harus jelas, konkret, dan mudah dipahami. Kata kerja operasional (KKO) menyatakan pada IPK 4.3.1 dan 4.3.2 tidak untuk mengukur aspek keterampilan. Menurut Sa'dun (2013) indikator pencapaian kompetensi harus menggunakan KKO yang dapat diukur/ diobservasi.

Susda Heleni dan Zulkarnain (2017) dalam penelitiannya mengatakan bahwa guru SMP/MTs di Pekanbaru masih merasa kesulitan dalam menyusun perangkat pembelajaran berdasarkan kurikulum 2013, hal ini dikarenakan guru belum memahami dengan baik tentang kurikulum 2013. Dalam hasil penelitiannya, diperoleh informasi mengenai kendala pelaksanaan Kurikulum 2013 yaitu salah satunya terkait perangkat pembelajaran. Silabus yang disusun oleh guru tidak memiliki komponen yang lengkap sesuai dengan permendikbud. RPP yang dibuat guru bukan dikembangkan berdasarkan silabus yang sudah dikemas, namun berdasarkan pengalaman mengajar materi pada 
tahun-tahun sebelumnya. Perangkat dibuat hanya terbatas pada persyaratan administrasi yang disediakan oleh guru tanpa memperhatikan tujuan yang ingin dicapai (Nur Atika, 2020). Guru juga mengalami kesulitan merancang LKPD yang dapat membantu peserta didik menemukan konsep mereka sendiri tentang materi yang sedang dipelajari dan dapat mengembangkan kemampuan pemecahan masalah matematika (Rahmi Fitria, 2020).

Berdasarkan masih rendahnya KPMM peserta didik serta pentingnya perangkat pembelajaran maka peneliti merasa perlu untuk merancang perangkat pembelajaran sebagai upaya untuk mengatasi hal tersebut. Oleh karena itu perlunya merancang perangkat pembelajaran dengan model PBL karena model ini memuat hal kemampuan pemecahan masalah matematis. Agar perangkat pembelajaran yang dikembangkan dapat berfungsi dengan baik dalam pembelajaran, maka perangkat pembelajaran tersebut haruslah valid dan praktis. Nieveen (Novrini, 2015) menyatakan bahwa perangkat pembelajaran dikatakan memiliki kualitas yang baik apabila perangkat tersebut valid dan praktis. Bertolak dari uraian di atas, maka peneliti bermaksud untuk mengembangkan suatu Perangkat Pembelajaran Matematika menggunakan model PBL yang valid dan praktis untuk memfasilitasi kemampuan pemecahan masalah matematis peserta didik.

\section{METODE}

Penelitian ini merupakan jenis penelitian pengembangan (research and development), dengan menggunakan model pengembangan 4-D yang dirancang oleh Thiagarajan, Semmel, dan Semmel. Prosedur pengembangan terdiri dari 1) tahap pendefinisian meliputi (a) analisis awal-akhir, (b) analisis siswa, (c) analisis tugas, (d) spesifikasi tujuan pencapaian hasil belajar, dan (e) analisis materi, 2) tahap perancangan meliputi (a) rancangan silabus, (b) rancangan RPP, (c) rancangan LKPD, 3) tahap pengembangan meliputi, (a) validasi ahli, (c) uji coba kelompok kecil. Namun pada tahap develop, uji coba dilakukan hanya sampai pada uji coba keterbacaan untuk melihat kepraktisan dari LKPD yang dikembangkan. Subjek pada penelitian ini adalah 10 peserta didik kelas VIII SMP Darma yudha. Instrumen yang digunakan untuk mengumpulkan data pada penelitian ini adalah lembar validasi untuk melihat kevalidan dari perangkat yang dikembangkan serta angket respon peserta didik untuk melihat kepraktisan dari perangkat yang dikembangkan.

Lembar validasi ini adalah angket berstruktur untuk mendapatkan skor penilaian terhadap Silabus, RPP dan LKPD serta angket tidak berstruktur untuk memperoleh saran dari validator terhadap perangkat pembelajaran yang dikembangkan. Kategori penilaian yang digunakan adalah kategori penilaian dari Sugiyono (2014) yang dimodifikasi dari kategori sangat sesuai, sesuai, tidak sesuai dan sangat tidak sesuai. Menurut Sa'dun Akbar (2013), perangkat pembelajaran dikatakan valid jika nilai rata-rata validasinya lebih dari $70 \%$ atau berada pada kategori valid atau sangat valid. 
Pengembangan Perangkat Pembelajaran Matematika dengan Penerapan Model Problem Based Learning (PBL) untuk Memfasilitasi Kemampuan Pemecahan Masalah Matematis Peserta Didik Kelas VIII SMP, Frengki Candra Gunawan Silalahi, Kartini, Nahor Murani Hutapea

117

Angket respon peserta didik adalah sebuah pernyataan mengenai perangkat pembelajaran yang harus dijawab oleh peserta didik. Kriteria penilaian angket respon peserta didik menggunakan kategori penilaian skala Gutman ya atau tidak. Menurut Sa'dun Akbar (2013), perangkat pembelajaran dikatakan praktis jika rata-rata hasil angket respon peserta didik lebih dari 70,01\% dengan kategori praktis atau sangat praktis.

\section{HASIL DAN PEMBAHASAN}

Penelitian ini merupakan jenis penelitian pengembangan (research and development), yang menghasilkan perangkat pembelajaran yang memenuhi kriteria valid dan praktis. Perangkat pembelajaran yang dikembangkan adalah silabus, RPP dan LKPD menggunakan model PBL pada materi relasi dan fungsi untuk peserta didik kelas VIII SMP. Perangkat pembelajaran yang peneliti kembangkan menggunakan model 4-D yang dirancang oleh Thiagarajan, Semmel, dan Semmel dengan empat tahapan yaitu tahap define (pendefinisian), tahap design (perancangan), tahap develop (pengembangan), tahap disseminate(penyebaran). Namun pada penelitian ini, tahap develop (pengembangan) hanya dilakukan sampai pada ujicoba kelompok kecil untuk melihat kepraktisan LKPD yang dikembangkan. Prosedur penelitian dan pengembangan perangkat pembelajaran dengan model 4-D terlihat pada Gambar 2 berikut.

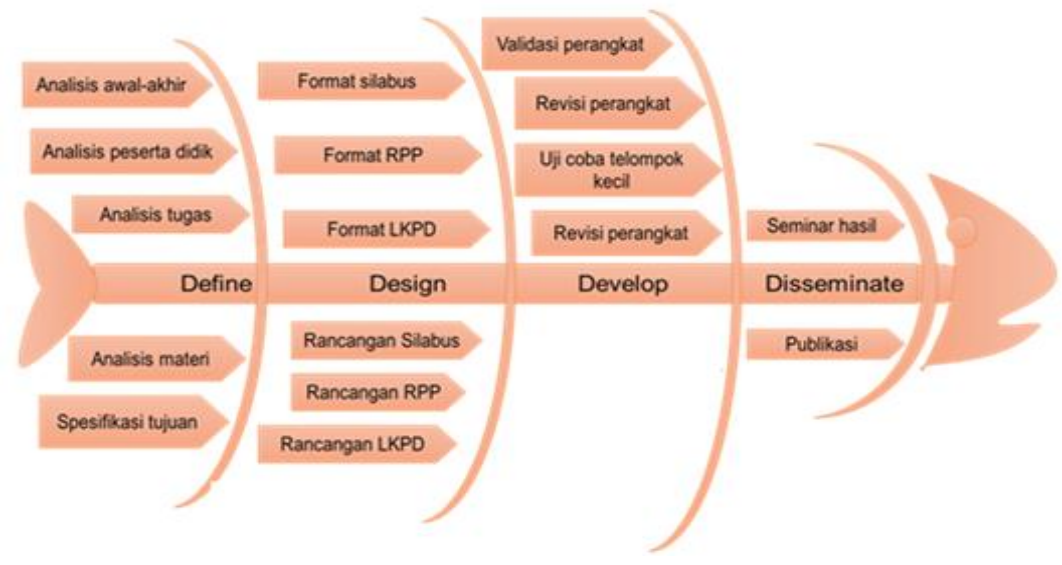

Gambar 2: Prosedur Pengembangan yang telah Dimodifikasi

Pada tahap define (pendefinisian) terdiri dari analisis awal-akhir, analisis peserta didik, analisis materi, analisis tugas, dan perumusan tujuan pembelajaran. Pada tahap analisis awal-akhir peneliti melakukan wawancara dengan guru bidang studi matematika. Berdasarkan hasil wawancara yang peneliti lakukan dengan beberapa orang guru matematika diketahui bahwa guru kesulitan dalam menyusun perangkat pembelajaran matematika, kegiatan pembelajaran yang dilakukan guru hanya menjelaskan konsep, prinsip dan prosedur tentang materi pembelajaran matematika dengan sedikit tanya jawab, memberikan contoh soal dan memberikan soal latihan, LKPD yang digunakan pada saat proses pembelajaran adalah LKPD yang hanya berisi ringkasan materi dan kumpulan soal-soal rutin, 
karakteristik peserta didik dikatakan cukup aktif jika dilakukan kegiatan belajar menggunkan metode diskusi. Contoh LKPD yang digunakan peserta didik terlihat pada Gambar 3 berikut.

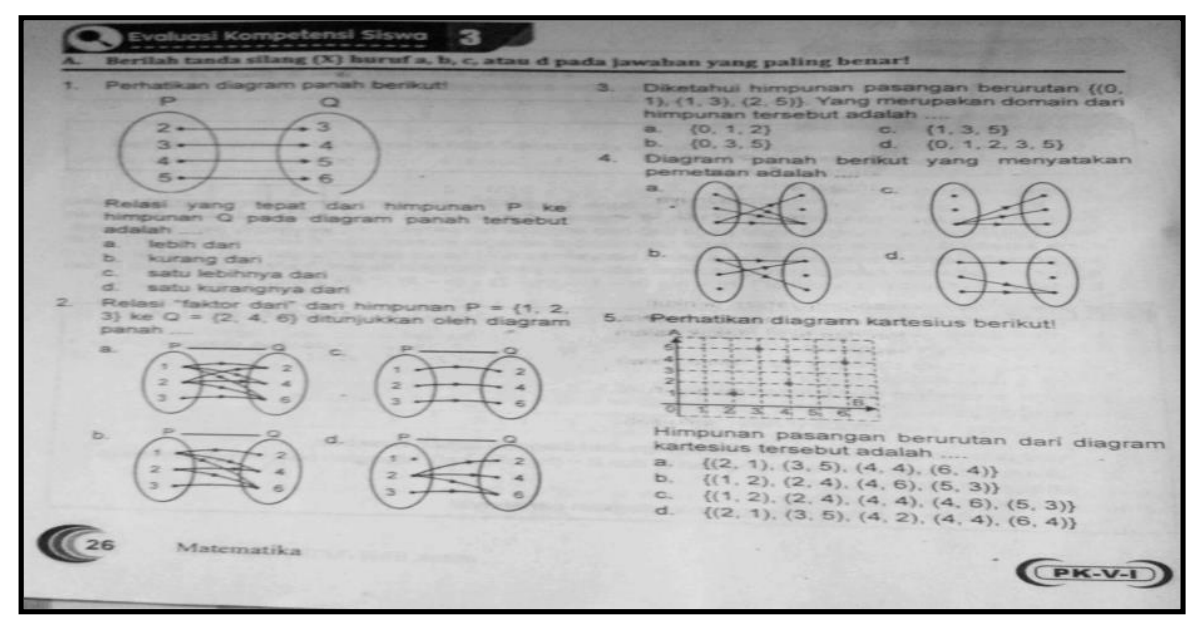

Gambar 3. Contoh LKPD yang Digunakan

Pada analisis peserta didik peneliti melihat kemampuan intelektual peserta didik yang menjadi subjek penelitian. Peserta didik yang menjadi subjek dalam penelitian ini adalah peserta didik kelas VIII SMP yang berusia rata-rata 12-14 tahun. Dengan kata lain, peserta didik kelas VIII SMP termasuk ke dalam golongan remaja. Menurut konsep piaget, kemampuan intelektual remaja telah sampai pada fase operasi formal dimana peserta didik umumnya sudah mampu berpikir abstrak, mampu menggunakan nalarnya, mampu mengkonstruksikan pengetahuannya sendiri (Idrus Alhaddad 2012). Kemampuan intelektual peserta didik yang berbeda-beda dijadikan peneliti sebagai pertimbangan dalam mengembangkan perangkat pembelajaran matematika menggunakan model pembelajaran yang tepat agar layak digunakan oleh peserta didik.

Pada tahap analisis materi peneliti mengidentifikasi materi-materi yang akan dikembangkan. Pada penelitian ini materi yang akan dikembangkan adalah relasi dan fungsi. Pemilihan materi dari pengembangan perangkat pembelajaran matematika ini didasarkan dari hasil wawancara dengan beberapa orang peserta didik yang didapatkan bahwa materi relasi dan fungsi termasuk materi yang sulit untuk dipahami oleh peserta didik. Pada penelitian ini perangkat pembelajaran disusun untuk empat kali pertemuan dengan menggunakan model PBL. Analisis tugas yang peneliti lakukan meliputi analisis terhadap kompetensi inti (KI) dan kompetensi dasar (KD) sesuai dengan materi yang dikembangkan. Peneliti menganalisis tugas pokok pada materi pembelajaran berupa aktivitas peserta didik untuk menemukan konsep materi, dalam hal ini aktivitas proses pembelajaran tercantum pada LKPD. 
Pengembangan Perangkat Pembelajaran Matematika dengan Penerapan Model Problem Based Learning (PBL) untuk Memfasilitasi Kemampuan Pemecahan Masalah Matematis Peserta Didik Kelas VIII SMP, Frengki Candra Gunawan Silalahi, Kartini, Nahor Murani Hutapea

119

Pada tahap design (perancangan) peneliti melakukan kegiatan yaitu memilih format untuk perangkat pembelajaran matematika yang dikembangkan berupa Silabus, RPP dan LKPD, selanjutnya peneliti membuat rancangan sesuai dengan format yang telah dibuat. Silabus dan RPP dirancang berdasarkan komponen silabus dan RPP dari Permendikbud Nomor 22 tahun 2016. Kegiatan pembelajaran dalam silabus dan RPP menggunakan model PBL dengan pendekatan saintifik. LKPD disusun berdasarkan langkah-langkah model PBL yaitu mengorientasikan peserta didik pada masalah, mengorganisasikan peserta didik untuk belajar, membimbing penyelidikan kelompok, mengembangkan dan menyajikan hasil karya, menganalisis dan mengevaluasi proses pemecahan masalah dengan pendekatakan saintifik yang memuat indikator kemampuan pemecahan masalah matematis.

Hasil rancangan LKPD terdiri dari sampul, isi LKPD dan latihan soal dengan kegiatan ayo berlatih. LKPD dirancang dengan warna yang menarik dan gambar yang sesuai dengan materi yang dipelajari untuk setiap pertemuannya. Sampul LKPD memuat judul, tujuan pembelajaran, kotak penulisan identitas peserta didik serta petunjuk penggunaan LKPD yang disertai dengan materi yang dipelajari. Bagian isi LKPD dirancang dengan kegiatan yang sama, namun isi yang dijabarkan dalam LKPD disesuaikan dengan materi yang dipelajari untuk setiap pertemuannya. Gambar berikut merupakan salah satu bagian sampul dan bagian isi LKPD yang peneliti dikembangkan.

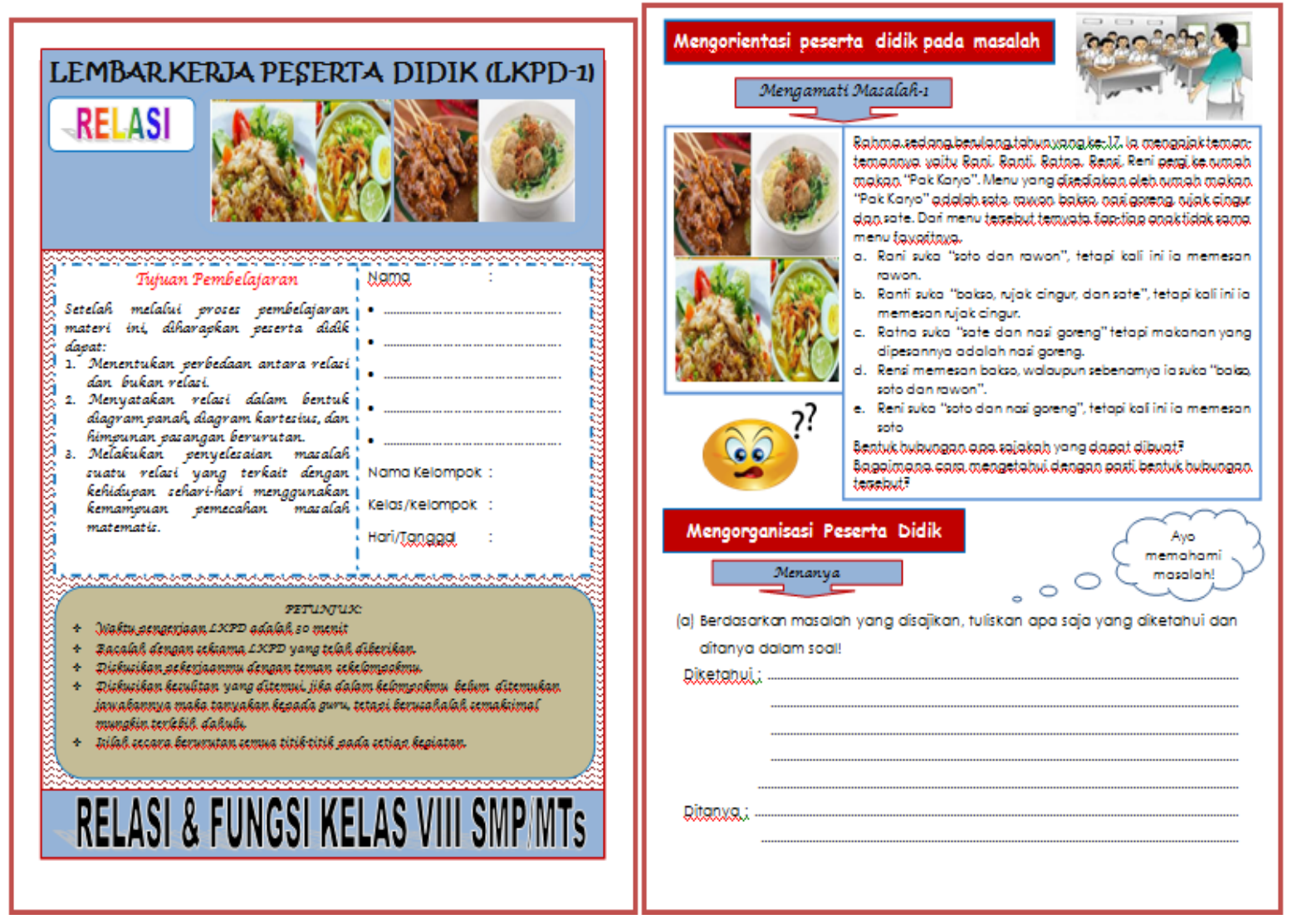

Gambar 1. Bagian Sampul dan Tahap Mengorientasi Peserta Didik Pada Masalah dan Mengorganisasikan Peserta Didik 
Rancangan LKPD pada Gambar 1 adalah rancangan pada sampul dan isi LKPD yaitu tahap mengorientasi peserta didik pada masalah dan mengorganisasikan peserta didik untuk belajar. Tahap mengorientasi peserta didik pada masalah merupakan tahap pertama dari model PBL. Pada tahap ini diberikan sebuah permasalahan dalam kehidupan nyata terkait dengan materi yang dipelajari. Tahap selanjutnya mengorganisasikan peserta didik untuk belajar yang merupakan tahap kedua dari model PBL. Pada tahap ini terdapat kegiatan menanya yang merupakan aktivitas dari pendekatan saintifik dimana pada kegiatan ini peserta didik menuliskan apa yang diketahui dan ditanyakan dari permasalahan yang diberikan yang merupakan indikator dari kemampuan pemecahan masalah matematis. Tahap membimbing penyelidikan kelompok merupakan tahap ketiga dari model PBL. Pada tahap ini terdapat kegiatan mengumpulkan informasi dan menalar yang merupakan aktivitas dari pendekatan saintifik. pada kegiatan ini peserta didik membuat model matematika dari apa yang diketahui dan ditanya yang merupakan indikator kemampuan pemecahan masalah matematis, selanjutnya peserta didik mengumpulkan informasi dan menyelesaikan masalah yang diberikan serta membuat jawaban sesuai permintaan soal yang telah disusun yang merupakan indikator kemampuan pemecahan masalah matematis. Tahap mengembangkan dan menyajikan hasil karya merupakan tahap keempat dari model PBL. Pada tahap ini terdapat kegiatan mengkomunikasikan yang merupakan aktivitas dari pendekatan saintifik. pada kegiatan ini peserta didik membuat laporan dari hasil kerjanya dan mempresentasikan hasil kerja yang telah diperoleh. Tahap menganalisis dan mengevaluasi proses pemecahan masalah merupakan tahap kelima dari model PBL. Pada tahap ini terdapat kegiatan mengkomunikasikan yang merupakan aktivitas dari pendekatan saintifik. pada kegiatan ini peserta didik menyamakan hasil kerja yang telah mereka peroleh.

Pada tahap develop (pengembangan) peneliti melakukan validasi kepada validator tentang perangkat pembelajaran yang telah disusun serta melakukan revisi sesuai saran validator. Peneliti selanjutnya melakukan uji coba terhadap perangkat yang telah divalidasi. Pada penelitian ini, validasi dilakukan oleh dua dosen dan 1 guru matematika sebagai validator. Saran-saran yang diberikan oleh validator dijadikan sebagai bahan masukan untuk perbaikan perangkat pembelajaran matematika yang dikembangkan. Hasil revisi dari validator merupakan perangkat pembelajaran yang telah memenuhi kriteria valid. Perangkat pembelajaran yang telah dinyatakan valid selanjutnya diuji coba terhadap peserta didik yang menjadi subjek penelitian. Pada penelitian ini, uji coba dilakukan hanya sampai pada uji coba kelompok kecil untuk mengetahui kepraktisan LKPD yang dikembangkan.

\section{Hasil Validasi Perangkat Pembelajaran}

Rata-rata hasil penilaian yang diberikan validator terhadap perangkat pembelajaran matematika yang peneliti kembangkan yaitu silabus, RPP dan LKPD dapat dilihat pada Tabel 1 berikut. 
Pengembangan Perangkat Pembelajaran Matematika dengan Penerapan Model Problem Based Learning (PBL) untuk Memfasilitasi Kemampuan Pemecahan Masalah Matematis Peserta Didik Kelas VIII SMP, Frengki Candra Gunawan Silalahi, Kartini, Nahor Murani Hutapea

Tabel 1. Hasil Validasi Silabus, RPP, dan LKPD

\begin{tabular}{|c|c|c|c|}
\hline Rata-rata Skor & Silabus & RPP & LKPD \\
\cline { 2 - 4 } Hasi Validasi & $84 \%$ & $87 \%$ & $85 \%$ \\
\hline
\end{tabular}

Sumber: Data Olahan Peneliti

Rata-rata hasil penilaian yang diberikan validator terhadap silabus yang dikembangkan berada pada kategori valid dengan rata-rata skor $84 \%$. Rata-rata hasil penilaian yang diberikan validator terhadap RPP yang dikembangkan berada pada kategori sangat valid dengan rata-rata skor $87 \%$. Ratarata hasil penilaian yang diberikan validator terhadap LKPD dikembangkan berada pada kategori sangat valid dengan rata-rata skor $85 \%$. Dapat disimpulkan bahwa perangkat pembelajaran matematika (silabus, RPP dan LKPD) yang peneliti kembangkan memenuhi kriteria valid, artinya perangkat tersebut dapat diuji cobakan. Namun terdapat beberapa komentar dan saran dari validator terhadap silabus dan RPP yaitu KKO yang digunakan, penulisan pada RRP, kisi-kisi soal disesuaikan dengan instrumen soal. Komentar dan saran yang diberikan validator terhadap LKPD yaitu perbaikan tulisan, menambahkan kalimat perintah untuk memudahkan peserta didik, memperbaiki redaksi soal.

\section{Hasil Uji Coba Kelompok Kecil}

Uji coba kelompok kecil dilakukan untuk melihat kepraktisan LKPD yang dikembangkan. Pada penelitian ini uji coba dilakukan terhadap 10 peserta didik kelas VIII SMP Darma Yudha. Semua peserta didik diminta untuk mengisi angket respon peserta didik setelah selesai mengerjakan semua LKPD. Aspek yang dinilai pada angket respon peserta didik yaitu tampilan dan bahasa, penyajian materi, kegiatan pembelajaran, dan manfaat. Respon peserta didik terhadap LKPD secara keseluruhan terlihat pada Tabel 2 berikut.

Tabel 2. Hasil Keterbacaan Terhadap LKPD

\begin{tabular}{|l|c|}
\hline \multicolumn{1}{|c|}{ LKPD Ke } & Rata-rata \\
\hline Aspek Tampilan dan Bahasa & $82 \%$ \\
\hline Aspek Penyajian Materi & $81 \%$ \\
\hline Aspek Kegiatan Pembelajaran & $79 \%$ \\
\hline Aspek Manfaat & $82 \%$ \\
\hline \multicolumn{2}{|c|}{ Rata-rata } \\
\hline \multicolumn{2}{|c|}{ Rata-rata Keseluruhan } \\
\hline
\end{tabular}

Sumber: Data Olahan Peneliti 
Berdasarkan hasil angket respon peserta didik terhadap LKPD yang dikembangkan diperoleh bahwa rata-rata hasil dari LKPD-1 sampai LKPD-4 adalah 81\% dengan kategori praktis. Angket respon peserta didik pada aspek tampilan dan bahasa mencapai $82 \%$ dengan kategori praktis, untuk aspek penyajian materi mencapai $81 \%$ dengan kategori praktis, untuk aspek kegiatan pembelajaran mencapai 79\% dengan kategori praktis, untuk aspek manfaat mencapai $82 \%$ dengan kategori praktis. Artinya LKPD yang dikembangkan dapat digunakan dengan baik oleh peserta didik.

Pada aspek kegiatan pembelajaran diperoleh rata-rata hasil angket respon peserta didik 79\%, artinya LKPD yang disusun dengan langkah-langkah model PBL dapat digunakan dengan baik oleh peserta didik. Hal ini dapat memfasilitasi peserta didik dalam mengembangkan kemampuan pemecahan masalah matematis. Sejalan dengan yang disampaikan Arends (2008) bahwa model problem based learning (PBL) dapat membantu peserta didik dalam mengembangkan keterampilan berpikir, keterampilan menyelesaikan masalah, dan keterampilan intelektualnya. Hasil penelitian Sumartini (2016) dan Sri (2019), menunjukkan bahwa kemampuan pemecahan masalah matematis peserta didik meningkat dengan digunakannya model PBL.

Hasil penelitian Rizza Yustianingsih (2017) menunjukkan bahwa Perangkat pembelajaran yang dikembangkan dengan model PBL dinilai praktis untuk meningkatkan kemampuan pemecahan masalah matematis peserta didik Kelas VIII SMP. Penelitian selanjutnya dilakukan oleh Rahmi (2016) menunjukkan bahwa respon peserta didik terhadap perangkat pembelajaran yang berorientasi pada problem based learning (PBL) sudah menunjukkan respon yang positif, artinya perangkat pembelajaran yang dikembangkan dapat meningkatkan kemampuan pemecahan masalah matematis peserta didik. Jadi, model PBL cocok digunakan untuk memfasilitasi KPMM peserta didik sehingga perlu diupayakan pembelajaran dengan model PBL.

Peserta didik menyatakan bahwa LKPD yang dikembangkan membuat mereka senang belajar materi relasi dan fungsi, hal ini dikarenakan LKPD tersebut dikembangkan dengan penulisan, gambar, diagram, dan warna yang menarik sehingga peserta didik tidak jenuh dalam belajar dan dapat membantu mereka memahami materi relasi dan fungsi. Komentar yang disampaikan peserta didik dapat dilihat pada Gambar 2 berikut.

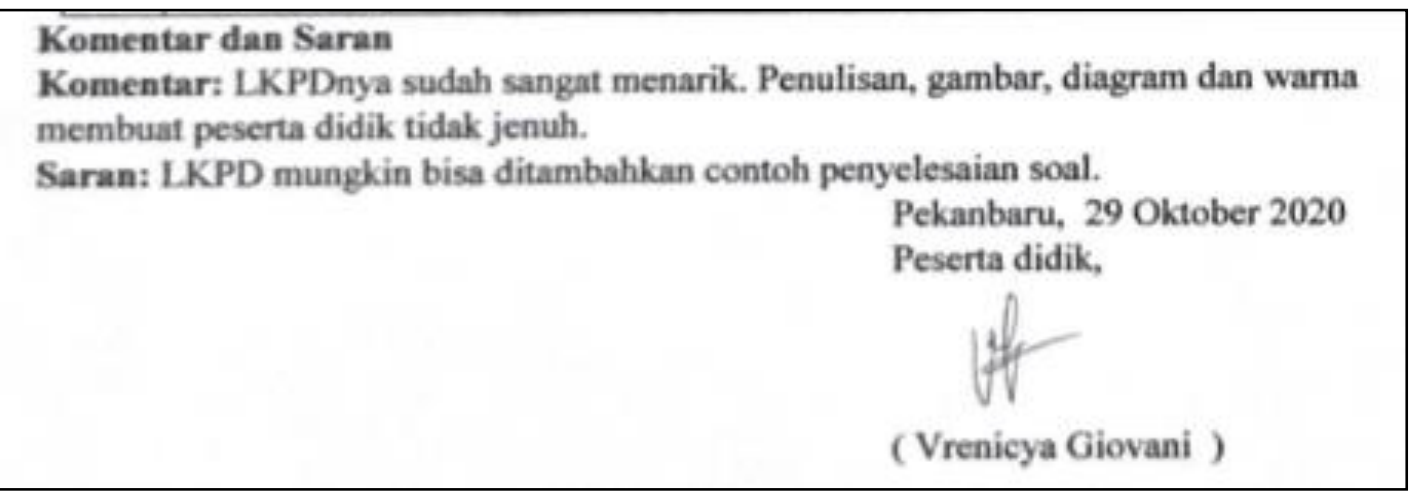

Gambar 2 Komentar Peserta didik 
Pengembangan Perangkat Pembelajaran Matematika dengan Penerapan Model Problem Based Learning (PBL) untuk Memfasilitasi Kemampuan Pemecahan Masalah Matematis Peserta Didik Kelas VIII SMP, Frengki Candra Gunawan Silalahi, Kartini, Nahor Murani Hutapea

123

Berdasarkan uraian hasil validasi terhadap Silabus, RPP dan LKPD, dan hasil uji coba kelompok kecil menggunakan angket respon peserta didik terhadap perangkat pembelajaran matematika pada materi relasi dan fungsi menggunakan model problem based learning (PBL) dapat disimpulkan bahwa Silabus, RPP dan LKPD yang dikembangkan sudah valid dan praktis untuk digunakan peserta didik kelas VIII SMP.

\section{KESIMPULAN}

Pengembangan perangkat pembelajaran matematika pada penelitian ini menggunakan model 4D (Define, Design, Development dan Disseminate). Penelitian pengembangan ini menghasilkan suatu perangkat pembelajaran matematika berupa silabus, RPP, dan LKPD pada materi relasi dan fungsi dengan menggunakan model Problem Based Learning (PBL). Hasil validasi dari validator menyatakan bahwa perangkat pembelajaran matematika (silabus, RPP, dan LKPD) yang dikembangkan mencapai kategori valid serta perangkat pembelajaran yang telah diujicobakan dinilai praktis.

\section{UCAPAN TERIMA KASIH}

Dalam menyelesaikan makalah ini, peneliti mendapatkan banyak bimbingan, arahan, motivasi dan doa dari berbagai pihak. Oleh karena itu, pada kesempatan ini peneliti mengucapkan terima kasih kepada pihak sebagai berikut.

Ibu Dr. Kartini, M.Si, selaku pembimbing I dan Dr. Nahor Murani Hutapea, M.Pd, selaku pembimbing II, yang telah memberikan bimbingan dan arahan kepada peneliti.

\section{REFERENSI}

Ariawan, Rezi. (2016). Pengembangan Instrumen Tes Kemampuan Pemecahan Masalah dan Komunikasi Matematis Pada Materi Bangun Ruang Sisi Datar. AdMathEdu, Vol 6 No 2.

Arends, R. I. (2012). Learning to teach (9th ed.). McGraw-Hill : New York, NY.

Arends, Richard. (2008). Learning to teach. Jogjakarta: Pustaka Pelajar.

Hidayat, Wahyu., Sariningsih \& Ratna. (2018). Kemampuan Pemecahan Masalah Matematis dan Adversity Quotient Siswa SMP Melalui Pembelajaran Open Ended. JNPM (Jurnal Nasional Pendidikan Matematika), Vol 2 No 1, hal 109-118.

Idrus, Alhaddad. (2012). Penerapan Teori Perkembangan Mental Piaget Pada Konsep Kekekalan Panjang. Infinity Journal, Vol 1 No 1, hal 31-44.

Novrini, Pargaulan Siagian \& Edy Surya., (2015), Pengembangan Perangkat Pembelajaran Berorientasi Problem Based Learning Untuk Meningkatkan Kemampuan Visual Thinking Dalam Pemecahan Masalah Matematis Siswa Kelas VIII SMP, Jurnal Paradigma, Vol 8 No 3, Desember 2015, hal 84-97. 
Nur Atika., Yenita Roza., \& Atma Murni., (2020). Development of Learning Tools by Application of Problem Based Learning Models to Improve Mathematical Communication Capabilities of Sequence and Series Materials. Journal of Educational Sciences, Vol 4 No 1, hal 62-72.

Rahmi Fitria., Nahor Murani Hutapea., \& H. Zulkarnain. (2020). Development of Mathematics Learning Devices by Applying Problem Based Learning to Increase Students Mathematical Solving Skills of Class VII Junior High School. Journal of Educational Sciences, Vol 4, no 2, April 2020, hal. 368-379.

Rahmi, Ramadhani. (2016). Pengembangan Perangkat Pembelajaran Matematika yang Berorientasi Pada Model Problem Based Learning. Jurnal Matematika Kreano-Inovatif, Vol 7 No 2, hal 116-122.

Rizza, Yustianingsih., Hendra, Syarifuddin \& Yerizon. (2017). Pengembangan Perangkat Pembelajaran Matematika Berbasis Problem Based Learning (PBL) Untuk Meningkatkan Kemampuan Pemecahan Masalah Peserta Didik Kelas VIII. Jurnal JNPM (Jurnal Nasional Pendidikan Matematika), Vol 1 No 2.

Sa'dun Akbar. (2013). Instrumen Perangkat Pembelajaran. Bandung: Remaja Rosdakarya.

Siti Mawaddah., \& Hana Anisah. (2015). 'Kemampuan Pemecahan Masalah Matematis Siswa Pada Pembelajaran Matematika Dengan Menggunakan Model Pembelajaran Generatif (Generative Learning) di SMP'. Jurnal Pendidikan Matematika Volume 3 Nomor 2 Oktober 2015, hal 166 175.

Sagala, Syaiful. (2011). Konsep dan makna Pembelajaran. Bandung: Alfabeta.

Sri Susilawati. (2019). Upaya Meningkatkan Kemampuan Pemecahan Masalah Matematika dan Kreativitas Siswa Melalui Model Pembelajaran Problem Based Learning. Pedagogia Jurnal Ilmu Pendidikan, Vol 17, no 1, hal. 67-79.

Sugiyono. (2014). Metode Penelitian Kuantitatif, Kualitatif, dan R\&D. Bandung: Penerbit Alfabeta.

Sumartini, T. S. (2016). Peningkatan Kemampuan Pemecahan Masalah Matematis Siswa melalui Pembelajaran Berbasis Masalah. Mosharafa: Jurnal Pendidikan Matematika, Vol 5 No 2, hal 148-158.

Susda Heleni \& Zulkarnain. (2017). Pelaksanaan Kurikulum 2013 pada Bidang Studi Matematika di Sekolah Menengah Pertama Negeri (SMPN) Kota Pekanbaru Tahun Pelajaran 2016/2017. AlKhwarizmi: Jurnal Pendidikan Matematika dan Ilmu Pengetahuan Alam, Vol 5, no 1, Maret 2017, hal. 43- 54.

Titi Solfitri, Syarifah Nur Siregar., \& Yenita Roza. (2017). Pengembangan Perangkat Pembelajaran Matematika Berbasis Kurikulum 2013 Pada Materi Bangun Ruang Sisi Datar Dan Lingkaran Untuk Peserta didik Kelas VIII Tingkat SMP/MTS. EduMath, Volume 4, Nomor 1, MeiOktober 2017, Program Studi Pendidikan Matematika STKIP PGRI Jombang, Jombang.

Trianto. (2009). Mendesain Model Pembelajaran Inovatif-progresif. Prenada Media Group, Jakarta.

Ulvah Sovia., Afriansyah., \& Ekasatya Aldila. (2016). Kemampuan Pemecahan Masalah Matematis Siswa Ditinjau Melalui Model Pembelajaran SAVI dan Konvensional. Jurnal Riset Pendidikan, Vol 2 No 2. 